RESEARCH PAPER RP1243

Part of Journal of Research of the National Bureau of Standards, Volume 23, September 1939

\title{
LENGTH CHANGES AND ENDOTHERMIC AND EXO- THERMIC EFFECTS DURING HEATING OF FLINT AND ALUMINOUS CLAYS
}

\author{
By Raymond A. Heindl and Lewis E. Mong
}

\begin{abstract}
Changes in length on heating from room temperature to $1,000^{\circ} \mathrm{C}$ and the temperatures at which endothermic and exothermic effects occurred were determined on flint clays from Kentucky, Missouri, Ohio, Pennsylvania, and Washington; on a plastic clay from Pennsylvania; on a hard kaolin and a bauxitic clay from Georgia; and on a Zettlitz kaolin and a diaspore from Missouri. Changes in the length of granular pieces and of pulverized materials were measured both in air and in an atmosphere of the products of gas combustion. The two ranges of temperature (approximately $500^{\circ}$ to $600^{\circ} \mathrm{C}$ and $925^{\circ}$ to $980^{\circ} \mathrm{C}$ ) in which very rapid contraction took place during heating were the same as those in which endothermic and exothermic reactions, respectively, occurred. The ranges of temperature in which rapid contraction took place were slightly lower for the pulverized than for the granular pieces of the clays, except for the Missouri clay, in which there was no difference.
\end{abstract}

\section{CONTENTS}

I. Introduction _......

II. Materials_............ 428

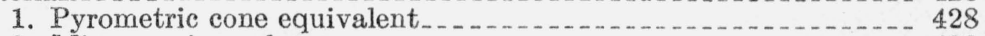

2. Microscopic analyses . . . . . .

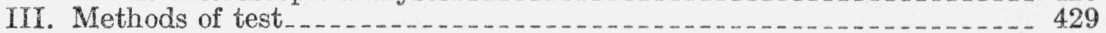

1. Length changes $\ldots \ldots \ldots \ldots$

(a) Preparation of test specimens

(b) Procedure ....... 429

(1) Atmospheric conditions

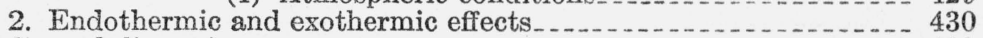

IV. Results and discussion $\ldots \ldots \ldots 30$

1. Missouri flint. .

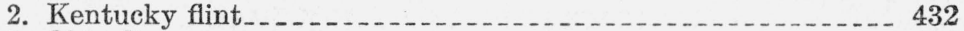

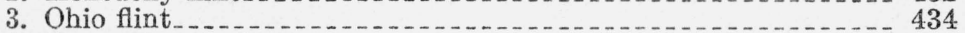

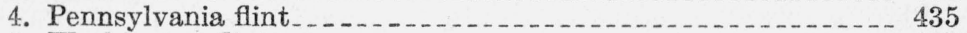

5. Washington flint

6. Tyrone plastic clay _...

7. Georgia kaolins . .

8. Diaspore

9. Zettlitz kaolin . .

10. Reproducibility of results

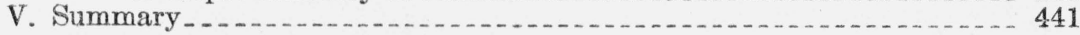

\section{INTRODUCTION}

The properties of fire-clay refractories are obviously dependent, at least in part, upon the changes which occur in the individual raw 
clays as they are heated.: Plans have been made to study finished refractory bodies prepared primarily from raw flint clays obtained from the various producing districts in this country. The present report contains the results of a study of the irreversible expansion and contraction characteristics of each of these raw flint clays when heated in air and when heated in an atmosphere of the products of gas combustion. Also, endothermic and exothermic effects were studied in most cases to determine whether there was any relation between these irreversible heat effects ${ }^{2}$ and the changes in length of the clays. In addition, several miscellaneous refractory materials were tested for comparison with the flint clays.

\section{MATERIALS}

One sample of flint clay was obtained from Kentucky, one from Missouri, and one from each of two deposits in Ohio, Pennsylvania, and Washington. Miscellaneous materials included one sample each of a refractory plastic clay from Pennsylvania, a hard kaolin from Georgia, a bauxitic clay from Georgia, a diaspore from Missouri, and a Zettlitz ${ }^{3}$ kaolin. The materials and their sources are listed in table 1.

TABLE 1.-Types of clay, sources, and pyrometric cone equivalents

\begin{tabular}{|c|c|c|}
\hline Material & Source & $\begin{array}{l}\text { Pyrometric } \\
\text { cone equiva- } \\
\text { lents }\end{array}$ \\
\hline Flint clay... & Missouri... & \\
\hline $\begin{array}{l}\text { Do } \\
\text { Flint clay a gravish tan }\end{array}$ & Kentucky & $\begin{array}{r}34-35 \\
34\end{array}$ \\
\hline Flint clay, a bluish & do & $\begin{array}{l}34 \\
35\end{array}$ \\
\hline Flint clay, light... & Ohio ... & $34-35$ \\
\hline Flint clay, dark & ...do.. & 32 \\
\hline Flint clay & Pennsylvania.. & $32-33$ \\
\hline Flint clay, Dean & do do................. & $34-35$ \\
\hline $\begin{array}{l}\text { Flint clay, Farrow } \\
\text { Flint clay, Dark Kummer } a\end{array}$ & Washington & 34 \\
\hline Flint clay, Dark Kummer a & - & 35 \\
\hline $\begin{array}{l}\text { Flint clay, Light Kummer }{ }^{a} \\
\text { Plastic clay, Tyrone... }\end{array}$ & Pennsylvania.......... & $\begin{array}{r}37 \\
32-33\end{array}$ \\
\hline Kaolin, hard & Georgia_...- & $34-35$ \\
\hline Kaolin, bauxitic................ & do & 37 \\
\hline 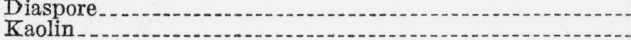 & $\begin{array}{l}\text { Missouri........ } \\
\text { Zettlitz }\end{array}$ & \\
\hline & & \\
\hline
\end{tabular}

a Tests were made of specimens of differently colored clay selected from the same sample.

\section{PYROMETRIC CONE EQUIVALENT}

The pyrometric cone equivalents (pce, or softening points) were determined according to the American Society for Testing Materials standard method, serial designation C24-35. ${ }^{4}$ The values, given in table 1, range from cone 32 to cone 37 for the materials tested.

\section{MICROSCOPIC ANALYSES ${ }^{5}$}

The petrographic microscope was used in making examinations of thin sections of Kentucky, Missouri, and Pennsylvania (Dean) flint clays to determine whether any differences in structure or composi-

1 R. A. Heindl, Progress report on investigation of sagger clays, J. Am. Ceram. Soc. 9, 131 (1926).

R. A. Heindl, A stuly of sagger clays and sagger bodies, J. Research NBS 15, 255 (1935) RP827.

2 Herbert Insley and Raymond H. Ewell, Thermal behavior of the kaolin minerals, J. Research NBS 14, 615 (1935) RP792.

3 For other tests, see the paper referred to in footnote 2.

4 Am. Soc. Testing Materials, Standards, pt. 2, Non-Metals, p. 299 (1936).

$\checkmark$ Made by H. Insley. 
tion could be detected. In each case the ground mass appeared to be largely amorphous under a high magnification. This ground mass had a mean index of refraction of about 1.55. Vermicular aggregates with a low to medium double refraction and a mean index of about 1.56 were fairly abundant and occurred as inclusions in the ground mass. These aggregates may have been kaolinite or halloysite. Clouds of minute particles (1 micron or less) with high double refraction and high index of refraction also occurred as inclusions in the ground mass. These particles were possibly rutile. The petrographic examination failed to show any significant differences between the three clays, with the possible exception that the material identified in the Pennsylvania flint as probably being rutile was present in larger aggregates than in the others.

\section{METHODS OF TEST}

\section{LENGTH CHANGES}

(a) PREPARATION OF TEST SPECIMENS

In order to obtain data on the flint clay in its unaltered structure, comparable to the larger particles used in batches from which refractory shapes and bricks are made, pieces for test were cut from large lumps. These pieces were finished by grinding them to cubes approximately 0.2 in. on a side. Furthermore, for making tests under different atmospheric conditions specimens were cut from the same lump of clay as the cubes to reduce possible variation.

Specimens representing the fine portion of the brick batch were prepared by pulverizing an average sample of flint clay to pass a No. 200 United States Standard Sieve. Cylinders 0.25 in. in diameter and 0.15 in. long were pressed from the slightly dampened material. Such specimens represented a uniform and intimately mixed sample of the clay. This was in contrast to the cubical specimens in which nonuniformity was indicated by differences in color of the clay.

In both cases specimens were dried overnight at approximately $105^{\circ} \mathrm{C}$

\section{(b) PROCEDURE}

The interferometer ${ }^{6}$ was used for making measurements, during heating, of the expansion or contraction of the raw clays. Measurements were made over the range from room temperature to $1,000^{\circ} \mathrm{C}$. A heating rate of $2.5^{\circ} \mathrm{C} / \mathrm{min}$ was used.

The linear shrinkage after heating and cooling the clays was measured with a micrometer.

(1) Atmospheric conditions.- - Length changes of the clays were measured under ordinary atmospheric conditions such as obtained in the muffle of an electrically heated furnace. They were measured also in an atmosphere of the products of gas combustion obtained by burning a small gas flame in the lower end of the furnace muffle. This atmosphere should partially simulate that present in many commercial kilns.

${ }^{6}$ George E. Merritt, The interference method of measuring thermal expansion, BS J. Research 10,59 (1933), RP515. 


\section{ENDOTHERMIC AND EXOTHERMIC EFFECTS}

The study of the thermal effects was limited to the determination of the relative magnitude of the endothermic and exothermic reactions and the temperature ranges over which they occurred.

For these tests, clays ground to pass a No. 200 sieve were used. The heat effects were measured by the modified differential-thermocouple method ${ }^{7}$ which has been made use of by many ceramic investigators in studies of clay materials. However, in place of the divided platinum cylinder usually used for the sample and reference material, a refractory thermocouple insulator, 1 by $1 / 2$ by $3 / 8$ in. with two holes slightly less than $1 / 4$ in. in diameter, was used. This was cemented in a vertical position to two legs, $3 / 4$ in. long.

The reference material was a clay calcined at $1,000^{\circ} \mathrm{C}$, and of the same fineness as the test specimens. It was considered suitable because it was inert and approached in composition the clays being tested. The reference material and the test material were packed tightly in the respective halves of the container around the junctions of the thermocouples. The rate of heating was $2.5^{\circ} \mathrm{C} / \mathrm{min}$. Readings of the temperature of the test sample and of the galvanometer deflection due to temperature difference between the materials in the two sides of the cylinder were taken at 1- to 5-min. intervals, depending on the rate of change of the differential temperature.

\section{RESULTS AND DISCUSSION}

\section{MISSOURI FLINT}

A series of specimens of Missouri flint clay, taken from different lumps of the 1,000-lb. lot received, was tested for change of length during heating. From visual examination the lumps selected appeared different in color and texture. Tests were made only on small cubes or pieces. The results of five such tests, all of which were made under ordinary atmospheric conditions, are shown in figure 1. The results show considerable differences in total length changes at $1,000^{\circ}$ $\mathrm{C}$, the range extending from 3.9 to 4.9 percent. The average linear shrinkages of the specimens after completing the heating and cooling: cycle ranged from 4.4 to 5.3 percent. The fact that each specimen was shorter after cooling than at $1,000^{\circ} \mathrm{C}$ was to be expected, since the contraction on heating was due to irreversible reactions, whereas that on cooling was ordinary reversible thermal contraction.

The curves show that the clays expanded uniformly and rather slowly from room temperature to within the range $470^{\circ}$ to $500^{\circ} \mathrm{C}$. This expansion amounted to approximately 0.3 percent. Contraction commenced thereafter and proceeded relatively slowly for approximately $60^{\circ} \mathrm{C}$, then very rapidly for approximately $50^{\circ} \mathrm{C}$. The contraction for this interval of approximately $110^{\circ} \mathrm{C}$ ranged for the different specimens from 1.0 to 1.8 percent. For the next interval of approximately $320^{\circ}\left(600^{\circ}\right.$ to $\left.920^{\circ} \mathrm{C}\right)$ the contraction proceeded again at a somewhat slower pace, resulting in 1.5 to 2.3 percent additional shortening. For the next $50^{\circ} \mathrm{C}$ interval (approximately $930^{\circ}$ to $980^{\circ} \mathrm{C}$ ) the contraction was very rapid again, ranging from 1.0 to 1.4 percent. After passing this range and up to $1,000^{\circ} \mathrm{C}$, con-

\footnotetext{
${ }^{7}$ Burgess and Le Chatelier, Measurements of high temperatures, $3 d$ ed., p. 383 (J. Wiley \& Sons, New York, N. Y., 1912).
} 
traction proceeded again at a slower rate. The curves, therefore, show two comparatively short ranges of temperature in which the contraction of the clays proceeded at a very rapid rate.

Additional tests of Missouri flint clay were made to determine whether the rate and extent of the contraction of the granules and that of the fines were different and also whether the contraction was affected by a change of atmosphere. Figure 2 (left) shows that when pieces were heated in an atmosphere of the products of gas combustion, the type of curve obtained was not greatly different from that already discussed. There are, however, two noteworthy features, namely: (a) The beginning of the first period (about $500^{\circ} \mathrm{C}$ ) of rapid contraction of the clay in air precedes that of the clay in an atmosphere of the products of gas combustion by at least $15^{\circ} \mathrm{C}$; however, in the beginning of the second period of rapid contraction (about $900^{\circ}$ C), it follows that of the clay tested in the spent gases by about $30^{\circ} \mathrm{C}$. (b) The total contraction at $1,000^{\circ} \mathrm{C}$ was the same in the two tests.

Figure 2 (right) shows the results ob- FIGURE 1.-Length changes during heating of five diftained in two atmospheres when tests were made on specimens pre-

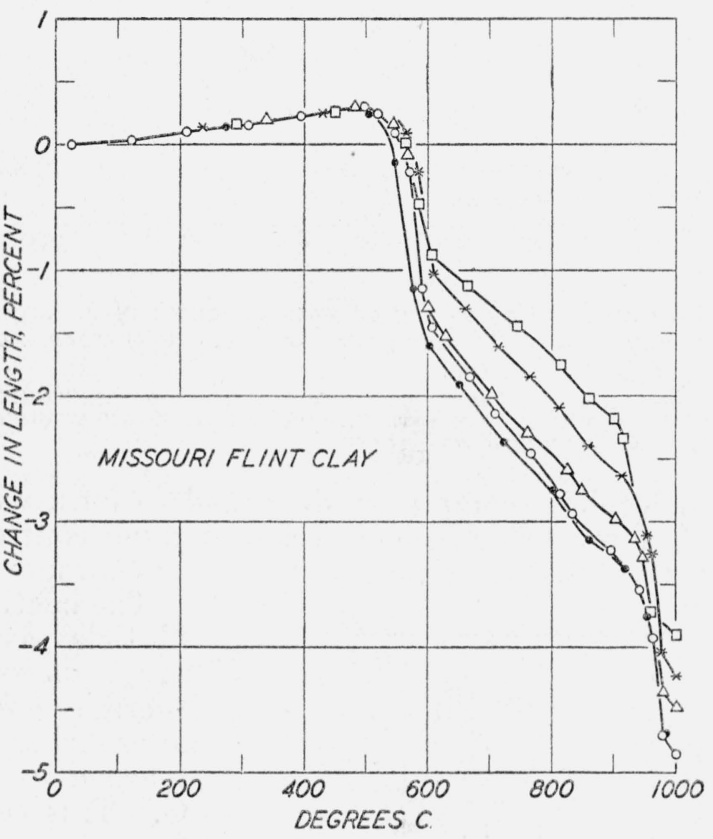

ferent pieces of clay selected from a sample of fint clay from Missouri.

Selection was based primarily on color.

pared from a composite sample of the fines. The trend of the expansion and contraction in this case was similar to that obtained on the coarse or granular particles. The rapid contraction which occurred between $500^{\circ}$ and $600^{\circ} \mathrm{C}$ was approximately 0.75 percent less and that between $800^{\circ}$ and $900^{\circ} \mathrm{C}$ was approximately 0.50 percent greater than that of the unpulverized clay.

Figure 3 compares contraction curves obtained from tests in air of coarse pieces of Missouri flint clay and of specimens prepared from the fines taken adjacent to the coarse pieces. Very little difference in results was obtained. This indicated that the differences shown in figure 2 between the pieces and the fines may be attributed to sampling.

In these tests the first period of rapid contraction occurred at about $500^{\circ} \mathrm{C}$, where according to J. W. Mellor, ${ }^{8}$ among others, the clay

\footnotetext{
${ }^{8}$ Chemical constitution of the clay molecule. Review of later theories, Trans. Ceram. Sac. 37, 118-125 (1938).
} 


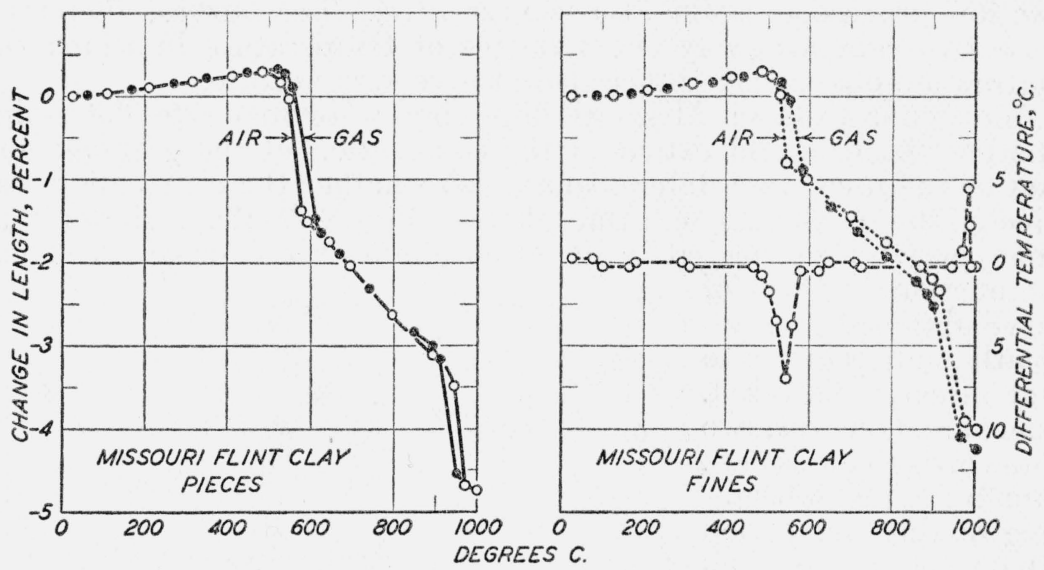

FIGURE 2.-Comparing changes in length of an average sample of Missouri fintclay fines (right) and granular pieces (left) when heated in air and in the products of gas combustion.

The difference between the pieces and the fines is not attributed to difference in grind but to variation in the material. The curve showing the endothermic and exothermic effects in the fines heated in air is given also in the graph on the right.

molecule is completely disrupted to form water, free silica, and free alumina. The second period of rapid contraction occurred at about $900^{\circ} \mathrm{C}$, where gamma alumina (see footnote 8 ) is formed.

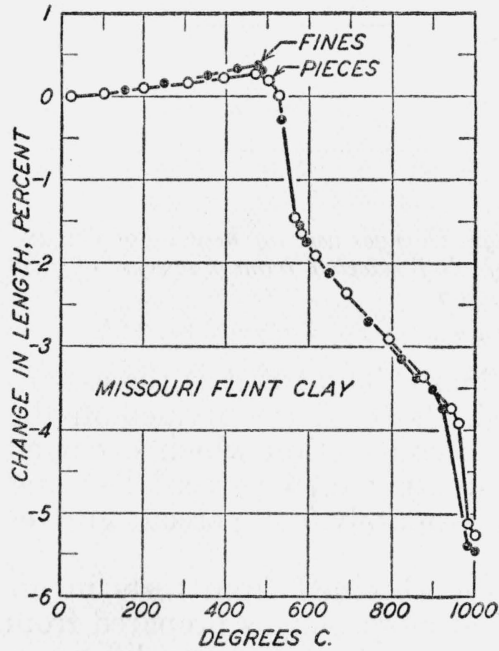

FIGURE 3.-No significant differences in changes in length between pieces and fines of Missouri flint clay were noted when specimens were prepared from adjacent material and heated in air. the results obtained in tests of the granular pieces of clay and of specimens prepared from the fines. The maximum expansion of flint clay as given on the right in figure 2 shows two effects. An endothermic effect took place between approximately $470^{\circ}$ and $580^{\circ} \mathrm{C}$ and reached its maximum at about $550^{\circ}$ C. This corresponds closely to the first period of rapid contraction. An exothermic effect took place between about $940^{\circ}$ and $990^{\circ} \mathrm{C}$ and reached its maximum at about $985^{\circ} \mathrm{C}$. This corresponds fairly closely to the second period of rapid contraction.

\section{KENTUCKY FLINT}

Figure 4 shows the results of tests of granular pieces and also of fines of Kentucky flint clay. Considering. either the pieces or the fines alone, only a slight difference was noted in the contraction characteristics when each was tested in air or in an atmosphere of the products of gas combustion. There was however, a considerable difference between

The heating curve for the Missouri 
the pieces was 0.4 percent and that of the fines 0.2 percent. Furthermore, the specimens made from the fines and tested in an atmosphere of burned gases reached their maximum expansion at a temperature $50^{\circ} \mathrm{C}$ higher than when tested in air. The shrinkage taking place during the first period of rapid contraction ranged from 1.75 to 2.0 percent and for the second period from 1.6 to 2.15 percent. The higher values were recorded with the fines, which is the reverse order from that obtained with the Missouri flint clay. The total contraction at $1,000^{\circ} \mathrm{C}$ ranged from 5.0 percent for the granular pieces to 6.0 percent for the fines.

To determine whether there was any difference in change of length with heating between pieces and fines of Kentucky flint clay, specimens were prepared from adjacent material to represent these two conditions. The results of the tests are shown on the left in figure 5 . In contrast with the Missouri clay, where there were no significant differences between the results ob-

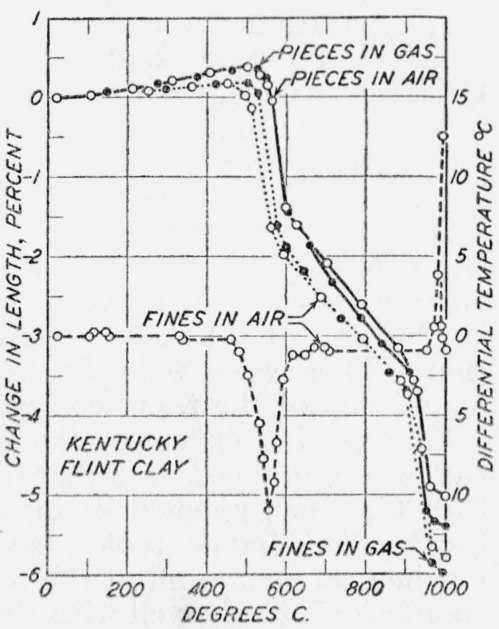

Figure 4.-Comparing changes in length during heating of granular pieces and fines of Kentucky flint clay delermined in air and in an atmosphere of the products of gas combustion

The endothermic and exothermic effects in the fines heated in air are shown also tained with the pieces and fines, the Kentucky clay showed a pronounced difference. The fines showed slightly less expansion up to $500^{\circ} \mathrm{C}$ and considerably greater con-

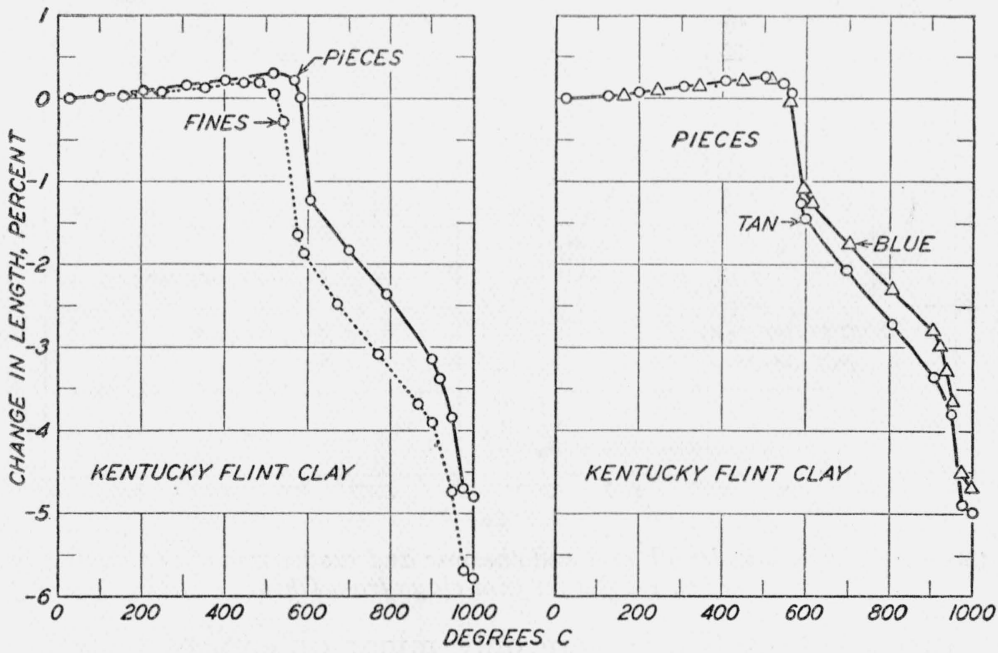

FIGURE 5.-Left, significant differences in measurements of change in length between pieces and fines of Kentucky flint clay were obtained when specimens were prepared from adjacent material and heated in air.

Right, changes in length of specimens from the same lump of clay but of two different colors which blended into one anather. 
traction between approximately $500^{\circ}$ and $600^{\circ} \mathrm{C}$. Also the total contraction up to $1,000^{\circ} \mathrm{C}$ was approximately 1.0 percent greater for the fines.

A separation was made of a light-bluish clay which appeared as streaks in lumps of Kentucky flint clay. As given in table 1, this material had a pyrometric cone equivalent of 35 ; the grayish-tan portion was 34 . The index of refraction of the bluish material was slightly higher than that of the tan, and the latter contained clouds of lowindex material. X-ray photographs indicated both materials to be kaolinites. The length changes obtained on heating of pieces taken adjacent to each other are shown on the right in figure 5. The bluish portion showed about 0.4 percent less contraction between $500^{\circ}$ and $600^{\circ} \mathrm{C}$ and about 0.25 percent less up to $1,000^{\circ} \mathrm{C}$ than the tan portion. There was little difference between the two materials in the magnitude of the rapid contraction between $900^{\circ}$ and $1,000^{\circ} \mathrm{C}$.

The heating curve for the Kentucky flint is given in figure 4 . A rather pronounced endothermic change occurred between $460^{\circ}$ and $610^{\circ} \mathrm{C}$, which reached its maximum at $550^{\circ} \mathrm{C}$. Also, a pronounced exothermic change took place between $960^{\circ}$ and $1,000^{\circ} \mathrm{C}$, which reached its maximum at approximately $990^{\circ} \mathrm{C}$. These effects corresponded relatively well with the intervals of rapid contraction shown. in the change of length curves.

\section{OHIO FLINT}

There are two flint clays from Ohio listed in table 1. Figure 6 (left) shows the results of tests of the contraction of the light-colored flint

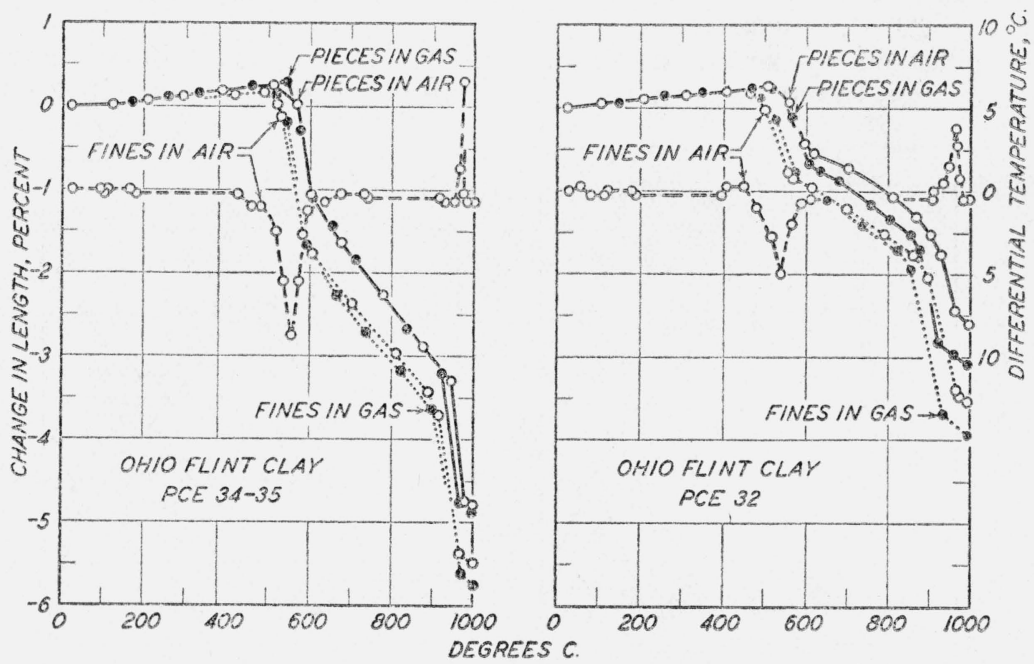

FIGURE 6.-Changes in length and endothermic and exothermic effects during heating of two different flint clays from Ohio.

clay (pce 34-35). There were only minor differences between this clay and the Kentucky flint clay. The expansion which occurred below $550^{\circ} \mathrm{C}$, the rapid contraction which occurred between approximately $500^{\circ}$ and $600^{\circ} \mathrm{C}$, and the total contraction up to $1,000^{\circ} \mathrm{C}$ were all slightly lower in the Ohio clay. 
Figure 6 (right) shows the results of tests of the second Ohio flint clay (pce 32). The fines, when tested in air, commenced to contract at a temperature about $40^{\circ} \mathrm{C}$ lower than that at which the pieces did. The shrinkage beginning at the end of the expansion period and ending at about $600^{\circ} \mathrm{C}$ in this case was only about one-half, and the total contraction up to $1,000^{\circ} \mathrm{C}$ was approximately two-thirds of that in the first Ohio clay. Both clays showed greater contraction when pulverized than when not pulverized.

The heating curves for the two Ohio flint clays are shown in the respective sections of figure 6 . No significant differences were noted between the heat effects of the two clays.

\section{PENNSYLVANIA FLINT}

There are two flint clays from Pennsylvania listed in table 1. Figure 7 shows the results of tests made on the clay which had a pyrometric cone equivalent of 32-33. Among the several notable differences between this clay and the others which have been discussed is that the expansion of the pieces was greater in the case of this clay and occurred over a longer temperature range. The fines showed an expansion of about the same magnitude as the fines of the other clays. Also, the Pennsylvania flint in the first period of contraction showed less change for both the fines and the pieces, but in the second period of rapid contraction this held true for the pieces only. Both the total contraction up to $1,000^{\circ} \mathrm{C}$ and the total shrinkage on cooling were low compared with the clays already discussed.

The results of tests of the Dean flint clay from Pennsylvania are given in figure 8 . The lumps of clay as received were a mixture

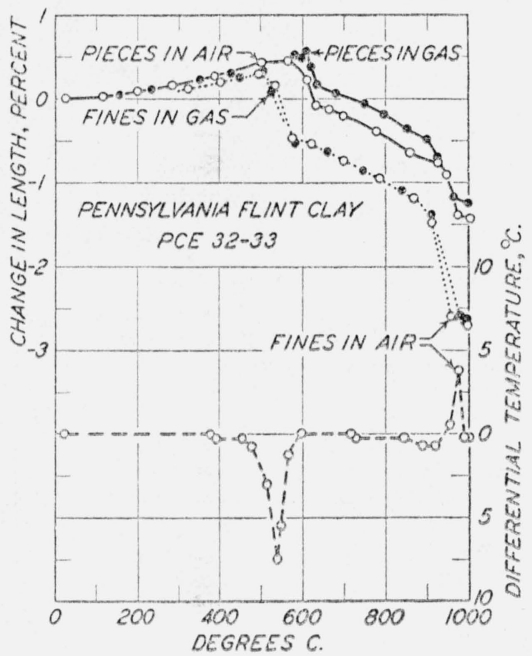

FIGURE 7.-Changes in length and endothermic and exothermic effects during heating of a fint clay from Pennsylvania.

The expansion of the clay occurred over a greater tem. perature range and the total length change was much less than obtained with flint clays from other sources. of very dark- to light-gray material. Results obtained with the pieces and the fines of the clay of an intermediate color, which formed the greater portion of the sample, are shown in the left section of figure 8 . The results on clay representing the extremes of the dark- and light-colored pieces are compared in the section on the right.

In the pieces the behavior of the clay was quite different from that of all other clays. The expansion proceeded slowly and uniformly, as noted in other clays, but extended over a slightly greater temperature range. Then with almost explosive violence the particular pieces of clay tested (fig. 8) expanded about three times as much within $50^{\circ} \mathrm{C}$ as they had within the preceding $500^{\circ} \mathrm{C}$. Immediately thereafter, for approximately $70^{\circ} \mathrm{C}$, fairly rapid contraction took place, which, however, was small in extent and slow when compared 
to that obtained with clays from the other States. The same diminution of extent and rapidity applied to the contraction which occurred between $900^{\circ}$ and $1,000^{\circ} \mathrm{C}$. Because of the high expansion and relatively lower contraction occurring below $650^{\circ} \mathrm{C}$, the length of the specimen at $1,000^{\circ} \mathrm{C}$ in one case was greater and in the other cases very little less than the original length.

Figure 8 also shows the results of tests of the pulverized clay. The appearance of the curves is very similar to that shown for specimens made from the fines of other flint clays. It is apparent that pulverizing the clays eliminated the causes of the rapid expansion between $500^{\circ}$ and $600^{\circ} \mathrm{C}$. This may possibly be accounted for by the destruction of lamination planes as discussed by J. O. Everhart. ${ }^{9}$ Also, since this clay was much harder than the other flint clays, pulverizing could facilitate the escape of the water or steam. In the granular pieces the steam might build up considerable pressure before

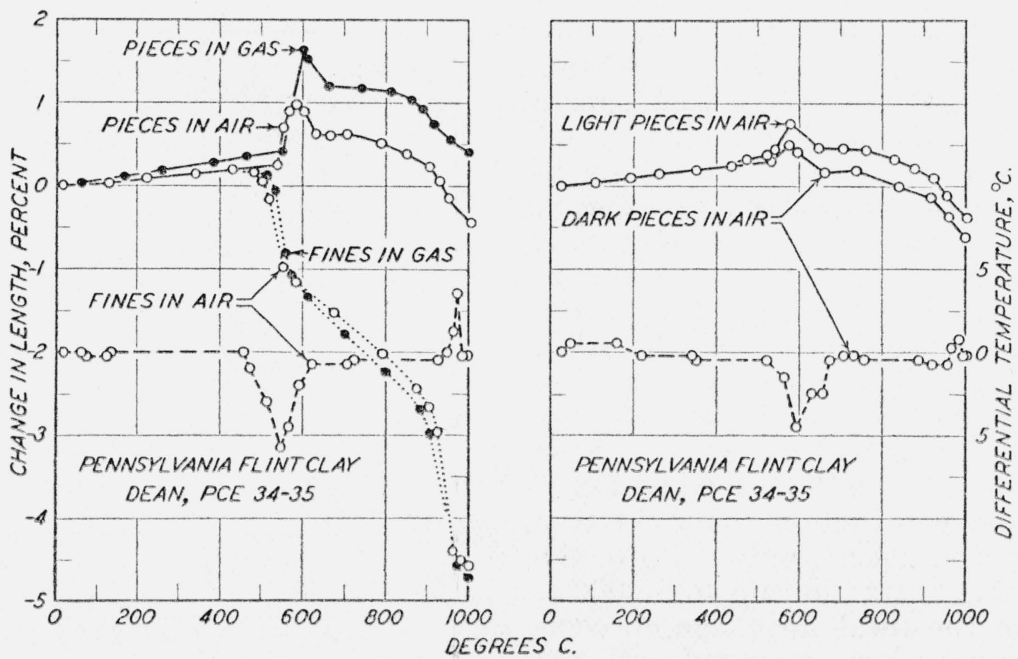

Frgure 8.--Changes in length and endothermic and exothermic effects during heating of a second flint (Dean) clay from Pennsylvania.

In the graph on the left the decided difference between the expansion and contraction of the granular pieces and the fines is shown. In the graph on the right are compared changes in length of pieces of clay taken from the same sample but different in color.

it was released. Changes in length of the fines were not significantly affected by the atmosphere. (See fig. 8.)

The curves showing the thermal changes which took place in this clay with heating to $1,000^{\circ} \mathrm{C}$ are given in figure 8 . Both the endothermic and exothermic peaks ${ }^{10}$ occurred at a higher temperature in the pieces than in the fines.

- Secondary expansion in refractory clays, J. Am. Ceram. Soc. 20, 353 (1937).

10 Some data were obtained on the efrect of atmosphere, size of particle, and rate of heating on the endothermic and exothermic effects of several of the clays. The data are limited in quantity and the values are, therefore, not reported. However, it was indicated that the exothermic peak in an atmosphere of the products of gas combustion (three tests) was reached at a slightly lower temperature than when tested in air. ucts of gas combustion (three tests) was reached at a slightly lower temperature than when tested in air. at a higher temperature with unpulverized clay (two tests) than with the fines. (See fig. 8.) In the single test made, a heating rate of $5^{\circ} \mathrm{C} / \mathrm{min}$ caused the endothermic effect to occur at an appreciably higher tem. perature than when a rate of $2,5^{\circ} \mathrm{C}$ was used. 

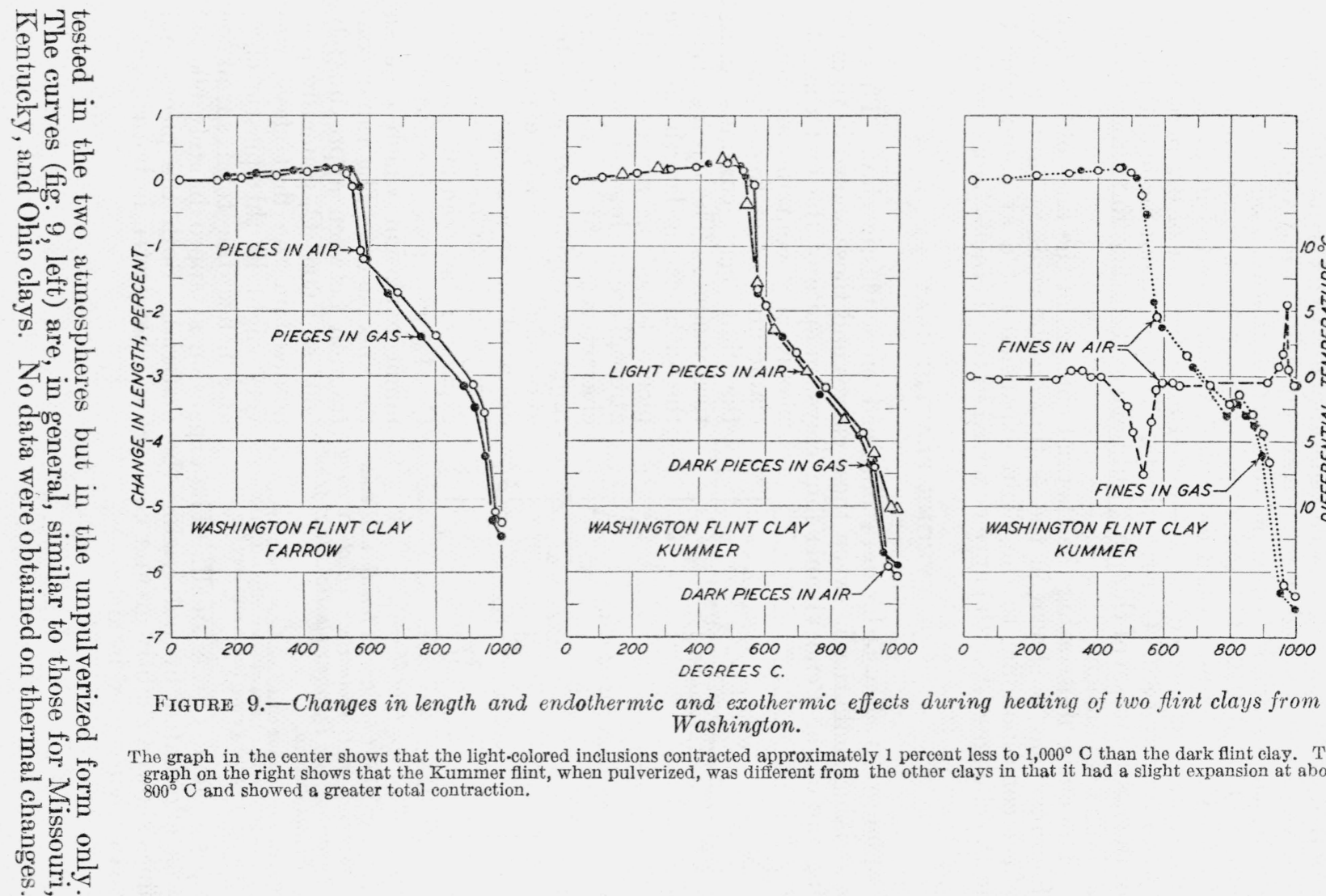

FIGURE 9.-Changes in length and endothermic and exothermic effects during heating of two flint clays from Washington.

The graph in the center shows that the light-colored inclusions contracted approximately 1 percent less to $1,000^{\circ} \mathrm{C}$ than the dark flint clay. The graph on the right shows that the Kummer flint, when pulverized, was different from the other clays in that it had a slight expansion at about $800^{\circ} \mathrm{C}$ and showed a greater total contraction. 
The Kummer flint clay was streaked with small quantities of a very light-colored material. This, when separated, gave a pyrometric cone equivalent of 37 as against 35 for the dark material. The curve for the light-colored material shows this clay to be significantly different from the darker clay (center graph, fig. 9), in that its maximum contraction up to $1,000^{\circ} \mathrm{C}$ was considerably less (5.0 versus 6.05 percent). The dark clay showed greater contraction than any other flint clay during the two periods of rapid contraction (between $500^{\circ}$ and $600^{\circ} \mathrm{C}$ and $850^{\circ}$ and $950^{\circ} \mathrm{C}$ ) and also a greater total contraction up to $1,000^{\circ} \mathrm{C}$. The pulverized dark clay, whether tested in air or in the atmosphere of burned gases, showed an expansion of 0.2 percent between $790^{\circ}$ and $820^{\circ} \mathrm{C}$ (fig. 9, right). Tests were not made of the fines of the light portion of this clay, but none of the other flint clays showed a similar expansion.

The curve illustrating the thermal changes of the fines of the dark Kummer clay is shown in the section on the right in figure 9 . No effect corresponding to the slight expansion noted at about $800^{\circ} \mathrm{C}$ in the change-of-length curve occurred in the thermal-change curve.

\section{TYRONE PLASTIC CLAY}

Figure 10 shows the data obtained on a plastic clay. There is a striking similarity between these curves and those shown in figure 7 for one of the Pennsylvania flint clays, in spite of the fact that the

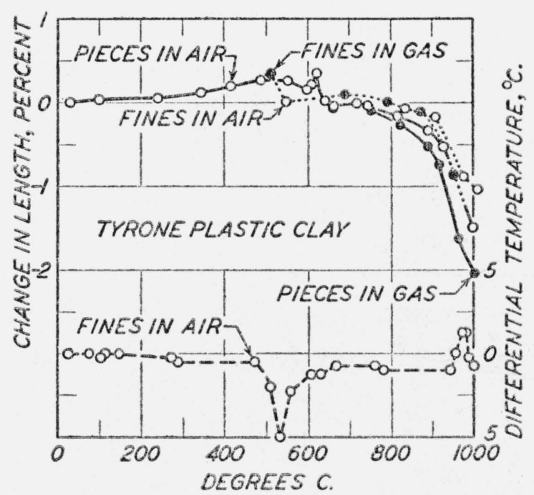

FIGURE 10.--Changes in length and endothermic and exothermic effects during heating of Tyrone plastic clay from Pennsylvania.

The curves showing changes of length for the pieces of this clay show a marked similarity with those for the pieces of the Pennsylvanis flint clay (fig. 7). plastic clay contains an appreciable amount of free silica and the flint clay contains practically none. The curves giving the changes in length for the pieces tested in air or in the atmosphere of burned gases are characterized by a slight but rapid expansion between $600^{\circ}$ and $620^{\circ}$ C. This expansion occurred after a slight contraction which followed the slow expansion between $20^{\circ}$ and $450^{\circ}$ C. It was accompanied by a minor explosion which cracked the specimens. The rapid contraction between approximately $500^{\circ}$ and $600^{\circ} \mathrm{C}$, generally pronounced in the flint clays, was very slight in this plastic clay, and hence the total shrinkage up to $1,000^{\circ} \mathrm{C}$ was small. The expansion at approximately $600^{\circ} \mathrm{C}$ was eliminated by pulverizing the material. Both the pieces and fines showed slightly greater contraction when tested in burned gases than when tested in air. 


\section{GEORGIA KAOLINS}

The results of tests of a Georgia hard kaolin ${ }^{11}$ tested in air are shown in figure 11 (left). The curves are very similar to those obtained for the Kentucky, Missouri, and Ohio flint clays. The effect of pulverizing was to increase slightly the magnitude of the rapid contraction which occurred between $500^{\circ}$ and $600^{\circ} \mathrm{C}$ as well as the total contraction up to $1,000^{\circ} \mathrm{C}$.

'The heating curve for this kaolin is given in the same section of figure 11. It is similar to heating curves obtained on some of the fiint clays.

A bauxitic Georgia kaolin was pulverized to obtain a composite sample, and the results of the tests are given in figure 11 (right).

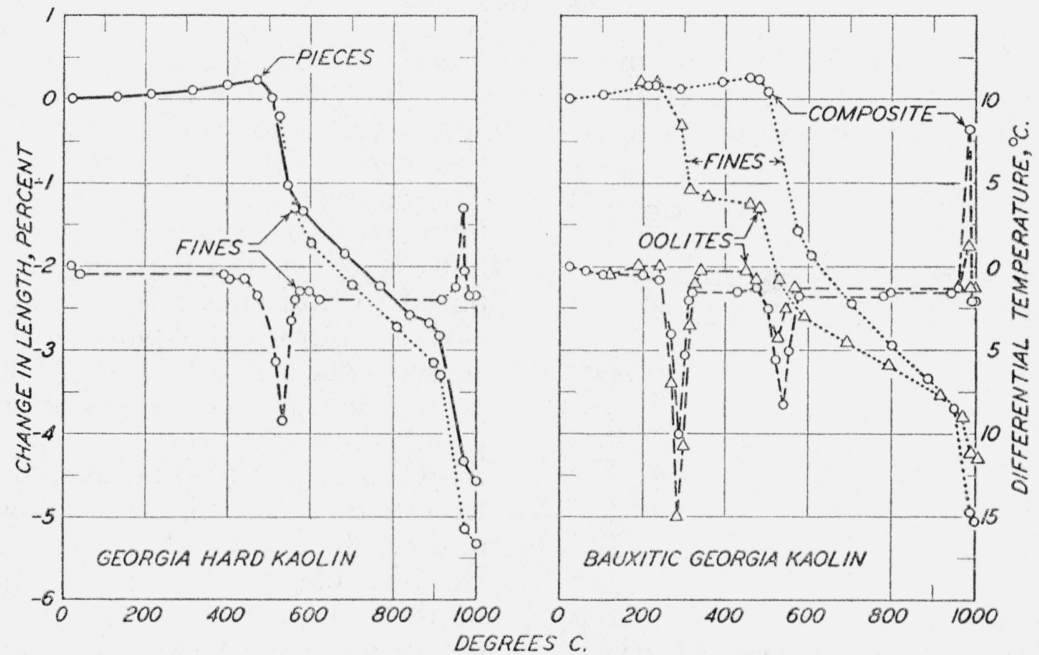

FIGURe 11.-Changes in length and endothermic and exothermic effects during heating in air of pulverized and unpulverized Georgia hard kaolin (left) and pulverized bauxitic Georgia kaolin and oolites taken from the latter (right).

The bauxitic kaolin and the oolites showed two endothermic effects and one exothermic. Only the oolites reflected the ârst thermal change by a large contraction between $200^{\circ}$ and $300^{\circ} \mathrm{C}$.

The curve is similar to those obtained for the flint clays, except for a slight contraction evident between about $230^{\circ}$ and $290^{\circ} \mathrm{C}$.

Specimens were made from oolites removed from the lumps of kaolin and pulverized to pass a No. 200 sieve. The manner in which the contraction of these specimens proceeded is shown also on the right in figure 11 . The first period of rapid contraction occurred between $230^{\circ}$ and $315^{\circ} \mathrm{C}$, the second between about $485^{\circ}$ and $580^{\circ}$ $\mathrm{C}$, and the third between $970^{\circ}$ and $990^{\circ} \mathrm{C}$.

11 The dehydration studies of the kaolin minerals by Ross and Kerr, The kaolin minerals, U. S. Geological Survey, Professional Paper 165-E (1930), Halloysite and allophane, U. S. Geological Survey, Paper 185-G (1934-35), show that these minerals lose water very slowly from room temperature to just below $400^{\circ} \mathrm{C}$ and very rapidly between $400^{\circ}$ and $500^{\circ} \mathrm{C}$. The period of rapid dehydration for both kaolinite and halloysite had in most cases been completed before $500^{\circ} \mathrm{C}$ had been reached. The data on change of length obtained in the present study indicated that a slow expansion occurred during most of that interval. Also, the temperature range of the first period of greatest contraction, which took place in the Georgia kaolin (also that of the flint clays, except the Dean), occurred between $500^{\circ}$ and $600^{\circ} \mathrm{C}$. The higher temperature range $\left(500^{\circ}\right.$ to $\left.600^{\circ} \mathrm{C}\right)$ at which dehydration of the kaolin occurred in the present study could be accounted for by the fact that a continuously rising temperature was used in making the tests, whereas the range ( $400^{\circ}$ to $500^{\circ} \mathrm{C}$ ) of rapid dehydration reported by Ross and Kerr was based on losses obtained at constant tem. peratures.

$$
168819-39-8
$$


The heating curves for the bauxitic Georgia kaolin and for the oolitic material appear in figure 11 (right). In each case a large endothermic effect took place between about $240^{\circ}$ and $320^{\circ} \mathrm{C}$, which reached its maximum at about $290^{\circ} \mathrm{C}$. This effect was probably due to the presence of gibbsite. ${ }^{12}$ Although the oolitic material showed such a pronounced change in the contraction curve in that temperature range, the bauxitic kaolin showed only a slight irregularity in its curve though the endothermic change was large in both instances. Both materials showed an endothermic change in the temperature range within which the clay molecule breaks down. In the case of the oolitic material this indicated the presence of kaolin, as also did the slight exothermic change between $960^{\circ}$ and $990^{\circ} \mathrm{C}$.

\section{DIASPORE}

The results of tests of pieces and fines of diaspore are given in figure 12. This figure shows that a slightly greater expansion occurred in the pieces between room temperature and $450^{\circ} \mathrm{C}$ than was

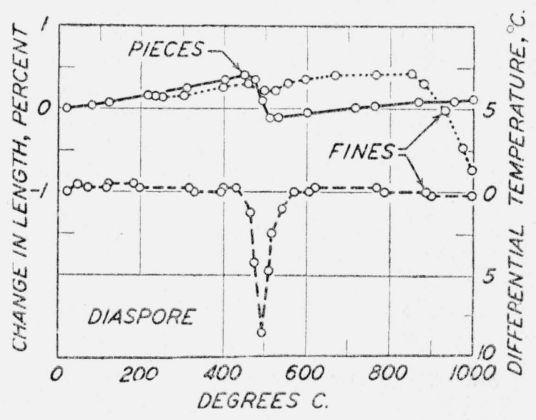

Figure 12.- Length changes and endothermic effect during heating in air of diaspor from Missouri.

the case with the flint clays. The contraction which occurred between $450^{\circ}$ and $510^{\circ} \mathrm{C}$ was, however, low (0.5 percent) compared to that shown by the flint clays. A gradual expansion was shown between $510^{\circ}$ and $1,000^{\circ}$ $\mathrm{C}$, which was the reverse of the trend shown by the flint clays. Also, no period of rapid contraction was shown between $900^{\circ}$ and $1,000^{\circ} \mathrm{C}$ such as occurred in the flint clays. Pulverizing the material had little effect on its expansion up to $460^{\circ} \mathrm{C}$. The entire contraction (less than 0.1 percent) between $460^{\circ}$ and $490^{\circ}$

$\mathrm{C}$ caused scarcely more than a ripple in the curve, and from there to $850^{\circ} \mathrm{C}$ very little change took place. However, between $850^{\circ}$ and $1,000^{\circ} \mathrm{C}$ a rather large contraction occurred (1.5 percent).

The heating curve showed but one break and that was due to an endothermic change which occurred between $400^{\circ}$ and $600^{\circ} \mathrm{C}$ and reached its maximum at $500^{\circ} \mathrm{C}$. The endothermic change was rather large, but only a slight change in length occurred in this temperature range.

\section{ZETTLITZ KAOLIN}

The results of two tests of Zettlitz kaolin are shown in figure 13 . Tests by W. Steger ${ }^{13}$ failed to show the rapid contraction between $500^{\circ}$ and $600^{\circ} \mathrm{C}$. It was for that reason that a sample of Zettlitz kaolin was tested. The same heating rate $\left(2.5^{\circ} \mathrm{C} / \mathrm{min}\right)$ was used with this kaolin as was used in all other tests; and, in addition, a heating rate of $6^{\circ} \mathrm{C}$, as used by Steger, was tried. Both curves (fig. 13) show the period of rapid contraction between about $540^{\circ}$

12 Unpublished data, H. Insley.

13 Ber. deut. keram. Ges. 19, 2 (1938). 
and $600^{\circ} \mathrm{C}$, though the higher heating rate caused the contraction to take place over a slightly greater temperature range. The total contraction at $1,000^{\circ} \mathrm{C}$ was about 3.25 percent, which is considerably greater than the 1.75 percent shown by Steger. The large difference would indicate that the two kaolins may have been of different purity.

J. F. Hyslop and A. McMurdo ${ }^{14}$ reported on changes in length of an English china clay and of a Missouri halloysite, but in neither case did they show a period of rapid contraction between $500^{\circ}$ and $600^{\circ} \mathrm{C}$.

\section{REPRODUCIBILITY OF RESULTS}

Tests were made on each of two sets of specimens prepared from the same small batch of fines of the Missouri and Kentucky clays to determine the reproducibility of the data on change of length. In each case, the difference in results between the first and second tests was less than 1 percent of the total length change.

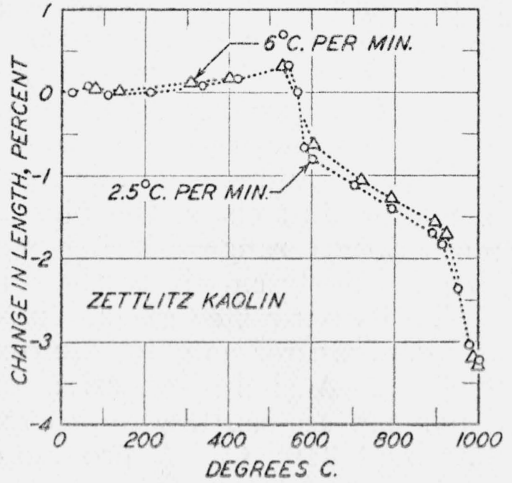

FIGURE 13.-Changing the rate of heating from $2.5^{\circ} \mathrm{C}$ to $6^{\circ} \mathrm{C}$ per minute does not greatly affect the results in measurements of change of length during heating in air of Zettlitz kaolin.

The peaks of the endothermic and exothermic changes made on duplicate samples of Missouri clay in air and in burned gases, and also of Kentucky clay in air only, did not vary more than $2^{\circ} \mathrm{C}$ between the first and second tests.

\section{SUMMARY}

A study was made of the changes in length and endothermic and exothermic effects between room temperature and $1,000^{\circ} \mathrm{C}$ in nine fint clays, three kaolins, and one each of a diaspore and a plastic clay. Also, their pyrometric cone equivalents were determined and some microscopic examinations were made.

The following results were noted:

All the flint clays (except one mined in Pennsylvania), as well as the Georgia and Zettlitz kaolins, showed a slight expansion between room temperature and approximately $500^{\circ} \mathrm{C}$, a rapid contraction of considerable proportions between approximately $500^{\circ}$ and $600^{\circ} \mathrm{C}$, a gradual contraction between about $600^{\circ}$ and $925^{\circ} \mathrm{C}$, a rapid contraction between approximately $925^{\circ}$ and $980^{\circ} \mathrm{C}$, and a slower contraction again from there to $1,000^{\circ}$ C. The Pennsylvania (Dean) flint, which was one of the exceptions in the unpulverized condition, showed a sharp expansion between about $540^{\circ}$ and $590^{\circ} \mathrm{C}$, but when pulverized through a No. 200 sieve acted similarly to the other flint clays.

In general, the pulverized clays showed greater total shrinkage up to $1,000^{\circ} \mathrm{C}$ than the unpulverized.

Also, the ranges in temperature in which rapid contraction took place were slightly lower for the fines than for the coarse material. The Missouri flint clay showed no differences in these ranges when the two types of specimens were prepared from adjacent material.

11 Trans. Ceram. Soc. 37, 180 (1938). 
Much variation in the magnitude of the rapid contraction during heating occurred in specimens prepared from different lumps of a sample of flint clay as well as from the same lump. The nonuniformity of the clays could readily be determined by visual examination.

The one plastic refractory clay tested showed very little contraction in the $500^{\circ}$ to $900^{\circ} \mathrm{C}$ range, but between $900^{\circ}$ and $1,000^{\circ} \mathrm{C}$ showed approximately the same as that shown by some of the flint clays.

Most of the clays showed slightly greater contraction in an atmosphere of the products of gas combustion than in air.

Endothermic reactions took place between approximately $475^{\circ}$ and $575^{\circ} \mathrm{C}$ and exothermic reactions between about $940^{\circ}$ and $990^{\circ} \mathrm{C}$ in all the flint clays, the plastic clay, and the Georgia kaolin. The temperature ranges during which these reactions occurred corresponded fairly closely to those in which rapid contraction took place.

The bauxitic Georgia kaolin contracted rapidly during two ranges of temperature, namely, approximately $480^{\circ}$ to $540^{\circ} \mathrm{C}$ and $970^{\circ}$ to $990^{\circ} \mathrm{C}$. A slight inflection or temporary reversal in trend from expansion to contraction to expansion was also indicated between $250^{\circ}$ and $310^{\circ}$ C. A pronounced endothermic effect was observed at the lower range of temperature and a moderately large one within the intermediate range. An exothermic effect was observed within the highest range.

The oolites from the bauxitic Georgia kaolin showed fairly pronounced contraction during three ranges of temperature, namely, approximately $250^{\circ}$ to $310^{\circ} \mathrm{C}, 480^{\circ}$ to $560^{\circ} \mathrm{C}$, and $970^{\circ}$ to $990^{\circ} \mathrm{C}$. An unusually large endothermic effect was observed at the lower range and a rather small one at the intermediate range. The exothermic effect, which reached its maximum at $980^{\circ} \mathrm{C}$, was small.

Diaspore showed contraction during one stage only, namely between $450^{\circ}$ and $510^{\circ} \mathrm{C}$, and but one heat effect, namely, an endothermic one between $450^{\circ}$ and $510^{\circ} \mathrm{C}$.

Washington, March 1, 1939. 